\title{
Reclassification of Aquaspirillum itersonii and Aquaspirillum peregrinum as Novispirillum itersonii gen. nov., comb. nov. and Insolitispirillum peregrinum gen. nov., comb. nov.
}

\author{
Jung-Hoon Yoon, So-Jung Kang, Sooyeon Park, Soo-Young Lee \\ and Tae-Kwang Oh
}

Correspondence

Jung-Hoon Yoon

jhyoon@kribb.re.kr
Korea Research Institute of Bioscience and Biotechnology (KRIBB), PO Box 115, Yusong, Taejon, Republic of Korea

\begin{abstract}
Phylogenetic analysis based on 16S rRNA gene sequences showed that Aquaspirillum itersonii and Aquaspirillum peregrinum form distinct phylogenetic lineages within the Alphaproteobacteria, whereas Aquaspirillum serpens, the type species of the genus Aquaspirillum, belongs to the Betaproteobacteria. A. itersonii and $A$. peregrinum exhibited 16S rRNA gene sequence similarity values of $82.0-82.4 \%$ to the type strain of $A$. serpens and of $91.8-92.0 \%$ to each other. $A$. itersonii and $A$. peregrinum were clearly distinguishable from $A$. serpens by differences in ubiquinone types and fatty acid profiles. A. itersonii subsp. itersonii LMG $4337^{\top}$ and $A$. itersonii subsp. nipponicum LMG $7370^{\top}$ contained $\mathrm{Q}-10$ as the predominant ubiquinone, and $A$. peregrinum subsp. peregrinum LMG $4340^{\top}$ and $A$. peregrinum subsp. integrum LMG $5407^{\top}$ contained Q-9 as the predominant ubiquinone, whereas $A$. serpens LMG $3734^{\top}$ had $\mathrm{Q}-8$ as the predominant ubiquinone. A. itersonii and $A$. peregrinum were also distinguishable from $A$. serpens by some differences in the fatty acid composition, including major fatty acids and hydroxy fatty acids. On the basis of these data, $A$. itersonii and $A$. peregrinum should be reclassified into two novel genera and species, for which the names Novispirillum itersonii gen. nov., comb. nov. and Insolitispirillum peregrinum gen. nov., comb. nov., respectively, are proposed.
\end{abstract}

The genus Aquaspirillum was created by Hylemon et al. (1973) with the descriptions of 13 species and, subsequently, further Aquaspirillum species have been described (Kumar et al., 1974; Strength et al., 1976; Aragno \& Schlegel, 1978; Maratea \& Blakemore, 1981; Butler et al., 1989). However, many Aquaspirillum species have been transferred to other genera or reclassified as members of novel genera (Schleifer et al., 1991; Pot et al., 1992; Cleenwerck et al., 2003; Wauters et al., 2003; Ding \& Yokota, 2004; Spring et al., 2004; Grabovich et al., 2006). Aquaspirillum itersonii and Aquaspirillum peregrinum were also found to be phylogenetically related more closely to the Alphaproteobacteria than to the Betaproteobacteria, to which the type species of the genus Aquaspirillum, Aquaspirillum serpens, belongs. A. itersonii and A. peregrinum were described by Hylemon et al. (1973) as a result of the reclassification of 'Spirillum itersonii' (Giesberger,

The GenBank/EMBL/DDBJ accession numbers for the $16 \mathrm{~S}$ rRNA gene sequences of strains LMG $4337^{\top}$, LMG $7370^{\top}$, LMG $4340^{\top}$ and LMG $5407^{\top}$ determined in this study are EF612765-EF612768, respectively.

Two-dimensional thin-layer chromatograms of polar lipids are available with the online version of this paper.
1936) and 'Spirillum peregrinum' (Pretorius, 1963), respectively. ' $S$. itersonii subsp. nipponicum' and ' $S$. peregrinum subsp. integrum', described by Terasaki (1973), were reclassified as A. itersonii subsp. nipponicum and $A$. peregrinum subsp. integrum by Terasaki (1979). A. itersonii and $A$. peregrinum were placed into the genus Aquaspirillum on the basis of morphological, physiological and nutritional characteristics and DNA base compositions (Hylemon et al., 1973; Terasaki, 1979). Accordingly, the aim of the present work was to determine the exact taxonomic positions of $A$. itersonii and A. peregrinum by a polyphasic characterization that included the determination of phenotypic and chemotaxonomic properties and a detailed phylogenetic analysis based on newly determined $16 \mathrm{~S}$ rRNA gene sequences.

A. itersonii subsp. itersonii LMG $4337^{\mathrm{T}}$, A. itersonii subsp. nipponicum LMG $7370^{\mathrm{T}}$, A. peregrinum subsp. peregrinum LMG $4340^{\mathrm{T}}$, A. peregrinum subsp. integrum LMG $5407^{\mathrm{T}}$ and $A$. serpens $\mathrm{LMG} 3734^{\mathrm{T}}$ were obtained from the Laboratorium voor Microbiologie Universiteit Gent (LMG), Gent, Belgium. To investigate their physiological and biochemical characteristics, $A$. itersonii and $A$. peregrinum strains were cultivated routinely at $28{ }^{\circ} \mathrm{C}$ in 


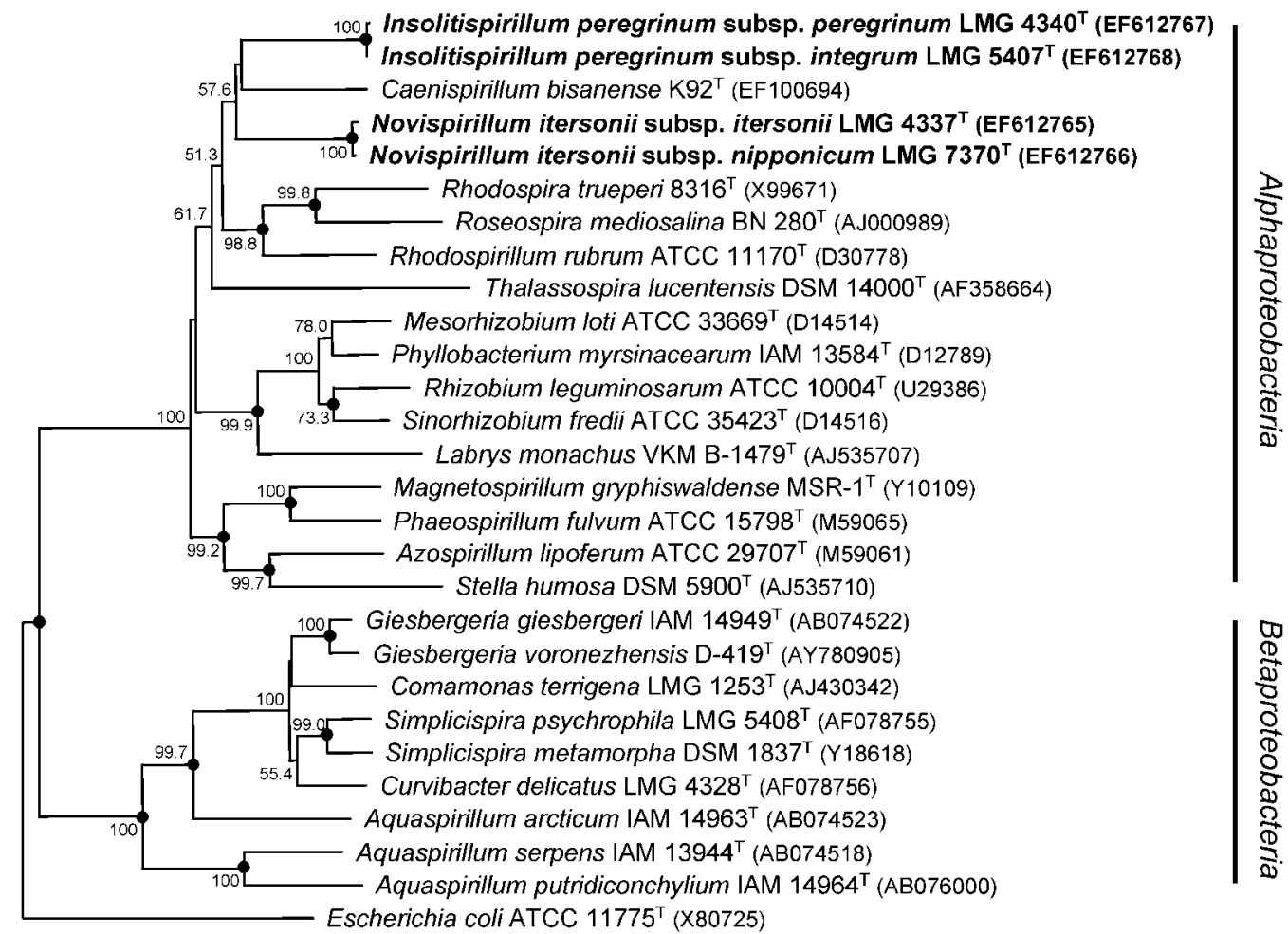

0.05

Fig. 1. Neighbour-joining phylogenetic tree based on 16S rRNA gene sequences showing the positions of Novispirillum (=Aquaspirillum) itersonii, Insolitispirillum (=Aquaspirillum) peregrinum and related taxa. Bootstrap values (expressed as percentages of 1000 replications) $>50 \%$ are shown at branch points. Dots indicate that the corresponding nodes were also recovered in trees generated with the maximum-likelihood and maximum-parsimony algorithms. Escherichia coli ATCC $11775^{\top}$ was used as an outgroup. Bar, 0.05 substitutions per nucleotide position.

LMG medium no. 8, which contained (1 distilled water $)^{-1}$ : $1 \mathrm{~g}$ succinic acid, $10 \mathrm{~g}$ peptone, $1 \mathrm{~g}\left(\mathrm{NH}_{4}\right)_{2} \mathrm{SO}_{4}, 1 \mathrm{~g}$ $\mathrm{MgSO}_{4} \cdot 7 \mathrm{H}_{2} \mathrm{O}, 2 \mathrm{mg} \mathrm{FeCl}_{3} \cdot 6 \mathrm{H}_{2} \mathrm{O}, 2 \mathrm{mg} \mathrm{MnSO}_{4} \cdot \mathrm{H}_{2} \mathrm{O}$ and $15 \mathrm{~g}$ agar, $\mathrm{pH}$ 7.0. Growth under anaerobic conditions was determined after incubation in a Forma anaerobic chamber on solid LMG medium no. 8 and on solid LMG medium no. 8 supplemented with potassium nitrate $(0.1 \%, \mathrm{w} / \mathrm{v})$, both of which had been prepared under a nitrogen atmosphere. Growth at various temperatures (4$45{ }^{\circ} \mathrm{C}$ ) was measured on solid LMG medium no. 8. Catalase and oxidase activities and hydrolysis of casein, gelatin, hypoxanthine, starch, Tweens 20, 40, 60 and 80, tyrosine, urea and xanthine were determined as described by Cowan \& Steel (1965). Aesculin hydrolysis and nitrate reduction were studied as described by Lanyi (1987). Susceptibility to antibiotics was tested on solid LMG medium no. 8 plates, using antibiotic discs containing the following antibiotics: polymyxin B, $100 \mathrm{U}$; streptomycin, $50 \mu \mathrm{g}$; penicillin $\mathrm{G}, 20 \mathrm{U}$; chloramphenicol, $100 \mu \mathrm{g}$; ampicillin, $10 \mu \mathrm{g}$; cephalothin, $30 \mu \mathrm{g}$; gentamicin, $30 \mu \mathrm{g}$; novobiocin, $5 \mu \mathrm{g}$; tetracycline, $30 \mu \mathrm{g}$; kanamycin, $30 \mu \mathrm{g}$; lincomycin, $15 \mu \mathrm{g}$; oleandomycin, $15 \mu \mathrm{g}$; neomycin, $30 \mu \mathrm{g}$; carbenicillin, $100 \mu \mathrm{g}$. Assimilation of various substrates, enzyme activities and other physiological and biochemical properties were tested by using the API 20E, API 20NE, API 50CH and API ZYM systems (bioMérieux); assimilation of various substrates was determined by inoculating the API 50CH strips with cells suspended in AUX medium (bioMérieux).

Cell biomass for DNA extraction and for analyses of isoprenoid quinones and polar lipids was obtained from cultivation in liquid LMG medium no. 8 at $28{ }^{\circ} \mathrm{C}$. Chromosomal DNA was isolated and purified according to the method described by Yoon et al. (1996), with the exception that RNase T1 was used in combination with RNase A to minimize RNA contamination. The 16S rRNA gene was amplified by PCR using two universal primers, $5^{\prime}$-GAGTTTGATCCTGGCTCAG-3' and 5'-AGAAAGGAGGTGATCCAGCC-3', as described previously (Yoon et al., 1998). Sequencing of the amplified 16S rRNA gene and phylogenetic analysis were performed as described previously (Yoon et al., 2003). Isoprenoid quinones were analysed by the method of Komagata \& Suzuki (1987), using reversed-phase HPLC. For cellular fatty acid analysis, 
Table 1. Percentage cellular fatty acid compositions of Aquaspirillum itersonii, Aquaspirillum peregrinum and Aquaspirillum serpens from this study

Strains: 1, A. itersonii subsp. itersonii LMG $4337^{\mathrm{T}} ; 2$, A. itersonii subsp. nipponicum LMG $7370^{\mathrm{T}} ; 3$, A. peregrinum subsp. peregrinum LMG $4340^{\mathrm{T}}$; 4, A. peregrinum subsp. integrum LMG $5407^{\mathrm{T}}$; 5 , A. serpens LMG $3734^{\mathrm{T}}$. Fatty acids that represented $<0.5 \%$ in all strains were omitted.

\begin{tabular}{|lccccc|}
\hline Fatty acid & $\mathbf{1}$ & $\mathbf{2}$ & $\mathbf{3}$ & $\mathbf{4}$ & $\mathbf{5}$ \\
\hline Straight chain & & & & & \\
$\mathrm{C}_{12: 0}$ & 3.6 & 3.7 & 2.9 & 3.0 & 4.4 \\
$\mathrm{C}_{14: 0}$ & 0.3 & - & - & 0.8 & 0.9 \\
$\mathrm{C}_{15: 0}$ & - & - & - & - & 0.8 \\
$\mathrm{C}_{16: 0}$ & 13.9 & 5.2 & 9.0 & 15.6 & 18.8 \\
$\mathrm{C}_{17: 0}$ & - & - & - & - & 0.6 \\
$\mathrm{C}_{18: 0}$ & 0.6 & 1.1 & 0.4 & 2.0 & 0.4 \\
Unsaturated & & & & & \\
$\mathrm{C}_{12: 1}$ & - & - & 8.0 & - & - \\
$\mathrm{C}_{15: 1} \omega 6 c$ & - & - & - & - & 0.9 \\
$\mathrm{C}_{16: 1} \omega 5 c$ & 1.7 & 0.8 & 1.8 & 1.3 & 0.2 \\
$\mathrm{C}_{17: 1} \omega 6 c$ & 0.2 & 0.2 & - & - & 0.9 \\
$\mathrm{C}_{18: 1} \omega 5 c$ & 0.7 & 1.9 & 1.0 & 1.5 & - \\
$\mathrm{C}_{18: 1} \omega 7 c$ & 54.2 & 67.2 & 49.2 & 53.9 & 14.5 \\
Hydroxy & & & & & \\
$\mathrm{C}_{12: 0} 3-\mathrm{OH}$ & - & - & - & - & 5.5 \\
$\mathrm{C}_{16: 0} 3-\mathrm{OH}$ & 2.8 & 2.6 & 2.5 & 2.3 & - \\
$\mathrm{C}_{18: 1} 2-\mathrm{OH}$ & 0.5 & 4.1 & 6.7 & 0.4 & - \\
$\mathrm{C}_{18: 0} 3-\mathrm{OH}$ & 1.1 & 1.6 & 0.4 & 0.8 & - \\
Unknown & & & & & \\
$\mathrm{ECL}^{*} 14.502$ & 0.5 & 0.4 & 0.4 & 0.5 & - \\
Summed features $\dagger$ & & & & & \\
2 & 2.8 & 3.0 & 3.0 & 2.8 & - \\
3 & 16.7 & 7.9 & 14.5 & 15.2 & 51.4 \\
\hline & & & & & \\
\hline
\end{tabular}

${ }^{\star}$ ECL, Equivalent chain length.

$\dagger$ Summed features represent groups of two or three fatty acids that could not be separated by GLC with the MIDI system. Summed feature 2 contained iso- $\mathrm{C}_{16: 1}$ and/or $\mathrm{C}_{14: 0} 3-\mathrm{OH}$. Summed feature 3 contained $\mathrm{C}_{16: 1} \omega 7 \mathrm{c}$ and/or iso- $\mathrm{C}_{15: 0} 2-\mathrm{OH}$.

cell biomass of the five strains was harvested from solid LMG medium no. 8 plates after incubation for 3 days at $28{ }^{\circ} \mathrm{C}$. Fatty acids were extracted and fatty acid methyl esters were prepared according to the standard protocol of the MIDI/ Hewlett Packard Microbial Identification system (Sasser, 1990). Polar lipids were extracted according to Minnikin et al. (1984) and identified by two-dimensional TLC after spraying with appropriate detection reagents (Minnikin et al., 1984; Komagata \& Suzuki, 1987). The DNA G+C content was determined by the method of Tamaoka \& Komagata (1984), with a modification that DNA was hydrolysed by using nuclease P1 (Sigma) and the resultant nucleotides were analysed by reversed-phase HPLC.

Almost-complete 16S rRNA gene sequences of $A$. itersonii subsp. itersonii $\mathrm{LMG} 4337^{\mathrm{T}}$, A. itersonii subsp. nipponicum LMG $7370^{\mathrm{T}}$, A. peregrinum subsp. peregrinum LMG $4340^{\mathrm{T}}$ and A. peregrinum subsp. integrum LMG $5407^{\mathrm{T}}$ determined in this study each comprised $1442 \mathrm{nt}$. There were five nucleotide differences in the sequences between $A$. itersonii subsp. itersonii LMG $4337^{\mathrm{T}}$ and A. itersonii subsp. nipponicum LMG $7370^{\mathrm{T}}$. There were two nucleotide differences between $A$. peregrinum subsp. peregrinum LMG $4340^{\mathrm{T}}$ and $A$. peregrinum subsp. integrum LMG $5407^{\mathrm{T}}$. In the phylogenetic tree, A. itersonii subsp. itersonii LMG $4337^{\mathrm{T}}, A$. itersonii subsp. nipponicum LMG $7370^{\mathrm{T}}$, A. peregrinum subsp. peregrinum LMG $4340^{\mathrm{T}}$ and $A$. peregrinum subsp. integrum LMG $5407^{\mathrm{T}}$ formed distinct phylogenetic lineages within the Alphaproteobacteria and were related distantly to the clade comprising A. serpens, the type species of the genus Aquaspirillum, which belongs to the Betaproteobacteria (Fig. 1). A. itersonii and A. peregrinum showed low $16 \mathrm{~S}$ rRNA gene sequence similarity values of $91.8-92.0 \%$ to each other, and similarity values of $82.2-82.4$ and $82.0 \%$ to the type strain of $A$. serpens, respectively.

The predominant isoprenoid quinone detected in $A$. itersonii subsp. itersonii LMG $4337^{\mathrm{T}}$ and A. itersonii subsp. nipponicum LMG $7370^{\mathrm{T}}$ was ubiquinone-10 (Q-10) at a peak area ratio of approximately $90-92 \%$. The predominant isoprenoid quinone detected in A. peregrinum subsp. peregrinum LMG $4340^{\mathrm{T}}$ and A. peregrinum subsp. integrum LMG $5407^{\mathrm{T}}$ was ubiquinone-9 (Q-9) at a peak area ratio of approximately $89-90 \%$. A. serpens LMG $3734^{\mathrm{T}}$ had Q-8 as the predominant ubiquinone, at a peak area ratio of approximately $95 \%$. The same results were obtained by Sakane \& Yokota (1994). Accordingly, A. itersonii and A. peregrinum could be distinguished clearly from $A$. serpens and from each other by differences in the predominant ubiqinone types. The cellular fatty acid profiles also distinguish $A$. itersonii and $A$. peregrinum from $A$. serpens (Table 1). A. itersonii and A. peregrinum contain $\mathrm{C}_{18: 1} \omega 7 c$ as the major fatty acid, whereas $A$. serpens contains $\mathrm{C}_{16: 1} \omega 7 c$ and/or iso- $\mathrm{C}_{15: 0}$ 2-OH (Table 1). A. itersonii and $A$. peregrinum were also distinguishable from $A$. serpens by some differences in fatty acid composition, including hydroxy fatty acids (Table 1), as also shown by the study of Sakane \& Yokota (1994). The phylogenetic and chemotaxonomic data suggest that $A$. itersonii and $A$. peregrinum should be placed in two different genera that are distinct from the genus Aquaspirillum. Therefore, we propose to reclassify A. itersonii and A. peregrinum as two novel genera and species, Novispirillum itersonii gen. nov., comb. nov. and Insolitispirillum peregrinum gen. nov., comb. nov., respectively.

\section{Description of Novispirillum gen. nov.}

Novispirillum (No'vi.spi.ril'lum. L. adj. novus new; N.L. dim. neut. n. spirillum a small spiral; N.L. neut. n. Novispirillum a new small spiral).

Cells are Gram-negative and helical. Catalase- and oxidasepositive. Nitrate is reduced to nitrogen gas. The predominant ubiquinone is Q-10. The major fatty acid is $\mathrm{C}_{18: 1} \omega 7 c$. The type species is Novispirillum itersonii (Giesberger 1936). 
Table 2. Phenotypic characteristics of Novispirillum (=Aquaspirillum) itersonii and Insolitispirillum (=Aquaspirillum) peregrinum determined in this study

Strains: 1, N. itersonii subsp. itersonii LMG 4337 $; 2$, N. itersonii subsp. nipponicum LMG $7370^{\mathrm{T}} ; 3, I$. peregrinum subsp. peregrinum LMG $4340^{\mathrm{T}}$; 4 , I. peregrinum subsp. integrum LMG $5407^{\mathrm{T}}$. Data are from this study. + , Positive reaction; -, negative reaction; w, weakly positive reaction. All strains are positive for growth at $15{ }^{\circ} \mathrm{C}$, catalase, oxidase, hydrolysis of aesculin, utilization of fructose, alkaline phosphatase, naphthol-AS-BIphosphohydrolase and susceptibility to streptomycin, chloramphenicol, gentamicin, tetracycline, kanamycin and neomycin. All strains are negative for Gram staining, growth at $10{ }^{\circ} \mathrm{C}$, hydrolysis of casein, gelatin, hypoxanthine, xanthine, starch and Tweens 20, 40, 60 and 80, utilization of erythritol, D-arabinose, Larabinose, ribose, D-xylose, L-xylose, adonitol, $\beta$-methyl-D-xyloside, galactose, glucose, mannose, sorbose, rhamnose, dulcitol, inositol, mannitol, sorbitol, $\alpha$-methyl-D-mannoside, $\alpha$-methyl-D-glucoside, $N$-acetylglucosamine, amygdalin, arbutin, salicin, cellobiose, maltose, lactose, melibiose, sucrose, trehalose, inulin, melezitose, raffinose, starch, glycogen, xylitol, gentiobiose, D-turanose, D-lyxose, D-tagatose, D-fucose, L-fucose, D-arabitol, L-arabitol, gluconate, 2-ketogluconate, 5-ketogluconate, caprate, adipate, citrate, phenylacetate, lipase (C14), valine arylamidase, cystine arylamidase, trypsin, $\alpha$-chymotrypsin, $\alpha$-galactosidase, $\beta$-galactosidase, $\beta$-glucuronidase, $\alpha$-glucosidase, $N$-acetylglucosaminidase, $\alpha$-mannosidase, $\alpha$-fucosidase and susceptibility to penicillin $\mathrm{G}$, ampicillin, cephalothin and oleandomycin.

\begin{tabular}{|c|c|c|c|c|}
\hline Characteristic & 1 & 2 & 3 & 4 \\
\hline Maximum growth temperature $\left({ }^{\circ} \mathrm{C}\right)$ & 43 & 41 & 39 & 39 \\
\hline Nitrate reduction & + & + & - & - \\
\hline Anaerobic growth with $\mathrm{KNO}_{3}$ & + & + & - & - \\
\hline \multicolumn{5}{|l|}{ Hydrolysis of: } \\
\hline Tyrosine & + & + & - & - \\
\hline Urea & - & - & + & + \\
\hline \multicolumn{5}{|l|}{ Utilization of: } \\
\hline Glycerol & - & + & - & - \\
\hline Aesculin & - & - & + & + \\
\hline Malate & + & + & - & - \\
\hline \multicolumn{5}{|l|}{ Enzyme activity (by API ZYM): } \\
\hline Esterase $(\mathrm{C} 4)$ & + & + & - & - \\
\hline Esterase lipase (C8) & + & + & - & - \\
\hline Leucine arylamidase & $\mathrm{w}$ & - & - & - \\
\hline Acid phosphatase & $\mathrm{w}$ & - & - & $\mathrm{w}$ \\
\hline$\beta$-Glucosidase & - & - & + & + \\
\hline \multicolumn{5}{|l|}{ Susceptibility to: } \\
\hline Polymyxin B & $\mathrm{W}$ & - & + & + \\
\hline Novobiocin & + & + & - & - \\
\hline Carbenicillin & - & - & + & + \\
\hline Lincomycin & - & + & - & - \\
\hline Predominant ubiquinone & Q-10 & Q-10 & Q-9 & Q-9 \\
\hline Major polar lipids ${ }^{\star}$ & PG, PE, AL & PG, PE, AL, L & PG, PE, AL, PL & PG, PE, AL, L \\
\hline DNA G $+C$ content $(\mathrm{mol} \%)$ & 63.2 & 64.7 & 62.4 & 62.3 \\
\hline
\end{tabular}

${ }^{\star} \mathrm{PG}$, Phosphatidylglycerol; PE, phosphatidylethanolamine; AL, unidentified aminolipid; L, unidentified lipid; PL, unidentified phospholipid.

\section{Description of Novispirillum itersonii (Giesberger 1936) comb. nov.}

Novispirillum itersonii (i.ter.so' ni.i. N.L. gen. n. itersonii named after G. Van Iterson, a Dutch bacteriologist).

Basonym: Aquaspirillum itersonii (Giesberger 1936).

The description is as that given by Hylemon et al. (1973) and Terasaki (1979). Characteristics of the type strain determined in this study are given in Table 2.

\section{Description of Novispirillum itersonii subsp. itersonii (Giesberger 1936) comb. nov.}

Novispirillum itersonii subsp. itersonii (i.ter.so'ni.i. N.L. gen. n. itersonii named after G. Van Iterson, a Dutch bacteriologist).

Basonym: Aquaspirillum itersonii subsp. itersonii (Giesberger 1936) Hylemon et al. 1973.

The description is as that given by Hylemon et al. (1973). Characteristics of the type strain determined in this study 
are given in Table 2. The type strain is ATCC $12639^{\mathrm{T}}=\mathrm{LMG} 4337^{\mathrm{T}}=$ CCUG $49447^{\mathrm{T}}$.

\section{Description of Novispirillum itersonii subsp. nipponicum (Terasaki 1973) comb. nov.}

Novispirillum itersonii subsp. nipponicum (nip.po'ni.cum. N.L. neut. adj. nipponicum pertaining to the country of Japan).

Basonym: Aquaspirillum itersonii subsp. nipponicum (Terasaki 1973) Terasaki 1979.

The description is as that given by Terasaki (1979). Characteristics of the type strain determined in this study are given in Table 2. The type strain is ATCC $33333^{\mathrm{T}}=$ LMG $7370^{\mathrm{T}}=$ CCUG $49448^{\mathrm{T}}$.

\section{Description of Insolitispirillum gen. nov.}

Insolitispirillum (In.so.li'ti.spi.ril'lum. L. adj. insolitus unaccustomed; N.L. dim. neut. n. spirillum a small spiral; N.L. neut. n. Insolitispirillum an unaccustomed small spiral).

Cells are Gram-negative and helical. Catalase- and oxidasepositive. Nitrate is not reduced. The predominant ubiquinone is Q-9. The major fatty acid is $\mathrm{C}_{18: 1} \omega 7 c$. The type species is Insolitispirillum peregrinum (Pretorius 1963).

\section{Description of Insolitispirillum peregrinum (Pretorius 1963) comb. nov.}

Insolitispirillum peregrinum (pe.re.gri'num. L. neut. adj. peregrinum strange, foreign).

Basonym: Aquaspirillum peregrinum (Pretorius 1963) Hylemon et al. 1973.

The description is as that given by Hylemon et al. (1973) and Terasaki (1979). Characteristics of the type strain determined in this study are given in Table 2 .

\section{Description of Insolitispirillum peregrinum subsp. peregrinum (Pretorius 1963) comb. nov.}

Insolitispirillum peregrinum subsp. peregrinum (pe.re.gri'num. L. neut. adj. peregrinum strange, foreign).

Basonym: Aquaspirillum peregrinum subsp. peregrinum (Pretorius 1963) Hylemon et al. 1973.

The description is as that given by Hylemon et al. (1973). Characteristics of the type strain determined in this study are given in Table 2. The type strain is ATCC $15387^{\mathrm{T}}=\mathrm{LMG} 4340^{\mathrm{T}}=$ CCUG $13795^{\mathrm{T}}=\mathrm{DSM} 1839^{\mathrm{T}}$.

\section{Description of Insolitispirillum peregrinum subsp. integrum (Terasaki 1973) comb. nov.}

Insolitispirillum peregrinum subsp. integrum (in'te.grum. L. neut. adj. integrum unchanged, referring to failure to form coccoid bodies).
Basonym: Aquaspirillum peregrinum subsp. integrum (Terasaki 1973) Terasaki 1979.

The description is as that given by Terasaki (1979). Characteristics of the type strain determined in this study are given in Table 2. The type strain is ATCC $33334^{\mathrm{T}}=$ LMG $5407^{\mathrm{T}}=$ CCUG $49449^{\mathrm{T}}=$ DSM $11589^{\mathrm{T}}$.

\section{Acknowledgements}

This work was supported by the 21C Frontier Program of Microbial Genomics and Applications (grant MG05-0401-2-0) from the Ministry of Science and Technology (MOST) of the Republic of Korea.

\section{References}

Aragno, M. \& Schlegel, H. G. (1978). Aquaspirillum autotrophicum, a new species of hydrogen-oxidizing, facultatively autotrophic bacteria. Int J Syst Bacteriol 28, 112-116.

Butler, B. J., McCallum, K. L. \& Inniss, W. E. (1989). Characterization of Aquaspirillum arcticum sp. nov., a new psychrophilic bacterium. Syst Appl Microbiol 12, 263-266.

Cleenwerck, I., De Wachter, M., Hoste, B., Janssens, D. \& Swings, J. (2003). Aquaspirillum dispar Hylemon et al. 1973 and Microvirgula aerodenitrificans Patureau et al. 1998 are subjective synonyms. Int J Syst Evol Microbiol 53, 1457-1459.

Cowan, S. T. \& Steel, K. J. (1965). Manual for the Identification of Medical Bacteria. London: Cambridge University Press.

Ding, L. \& Yokota, A. (2004). Proposals of Curvibacter gracilis gen. nov., sp. nov. and Herbaspirillum putei sp. nov. for bacterial isolates isolated from well water and reclassification of [Pseudomonas] huttiensis, [Pseudomonas] lanceolata, [Aquaspirillum] delicatum and [Aquaspirillum] autotrophicum as Herbaspirillum huttiense comb. nov., Curvibacter lanceolatus comb. nov., Curvibacter delicatus comb. nov. and Herbaspirillum autotrophicum comb. nov. Int J Syst Evol Microbiol 54, 2223-2230.

Giesberger, G. (1936). Beiträge zur Kenntnis der Gattung Spirillum Ehrb, pp. 1-136. Inaugural Dissertation Utrecht (in German).

Grabovich, M., Gavrish, E., Kuever, J., Lysenko, A. M., Podkopaeva, D. \& Dubinina, G. (2006). Proposal of Giesbergeria voronezhensis gen. nov., sp. nov. and G. kuznetsovii sp. nov. and reclassification of [Aquaspirillum] anulus, [A.] sinuosum and [A.] giesbergeri as Giesbergeria anulus comb. nov., G. sinuosa comb. nov. and G. giesbergeri comb. nov., and [Aquaspirillum] metamorphum and [A.] psychrophilum as Simplicispira metamorpha gen. nov., comb. nov. and S. psychrophila comb. nov. Int J Syst Evol Microbiol 56, 569-576.

Hylemon, P. B., Wells, J. S., Jr, Krieg, N. R. \& Jannasch, H. W. (1973). The genus Spirillum: a taxonomic study. Int J Syst Bacteriol 23, 340-380.

Komagata, K. \& Suzuki, K. (1987). Lipid and cell-wall analysis in bacterial systematics. Methods Microbiol 19, 161-207.

Kumar, R., Banerjee, A. K., Bowdre, J. H., McElroy, L. J. \& Krieg, N. R. (1974). Isolation, characterization, and taxonomy of Aquaspirillum bengal sp. nov. Int J Syst Bacteriol 24, 453-458.

Lanyi, B. (1987). Classical and rapid identification methods for medically important bacteria. Methods Microbiol 19, 1-67.

Maratea, D. \& Blakemore, R. P. (1981). Aquaspirillum magnetotacticum sp. nov., a magnetic spirillum. Int J Syst Bacteriol 31, 452-455.

Minnikin, D. E., O'Donnell, A. G., Goodfellow, M., Alderson, G., Athalye, M., Schaal, A. \& Parlett, J. H. (1984). An integrated 
procedure for the extraction of bacterial isoprenoid quinones and polar lipids. J Microbiol Methods 2, 233-241.

Pot, B., Willems, A., Gillis, M. \& De Ley, J. (1992). Intra- and intergeneric relationships of the genus Aquaspirillum: Prolinoborus, a new genus for Aquaspirillum fasciculus, with the species Prolinoborus fasciculus comb. nov. Int J Syst Bacteriol 42, 44-57.

Pretorius, W. A. (1963). A systematic study of genus Spirillum which occurs in oxidation ponds, with a description of a new species. J Gen Microbiol 32, 403-408.

Sakane, T. \& Yokota, A. (1994). Chemotaxonomic investigation of heterotrophic, aerobic and microaerophilic spirilla, the genera Aquaspirillum, Magnetospirillum and Oceanospirillum. Syst Appl Microbiol 17, 128-134.

Sasser, M. (1990). Identification of bacteria by gas chromatography of cellular fatty acids, MIDI Technical Note 101. Newark, DE: MIDI Inc.

Schleifer, K. H., Schüler, D., Spring, S., Weizenegger, M., Amann, R., Ludwig, W. \& Köhler, M. (1991). The genus Magnetospirillum gen. nov. description of Magnetospirillum gryphiswaldense sp. nov. and transfer of Aquaspirillum magnetotacticum to Magnetospirillum magnetotacticum comb. nov. Syst Appl Microbiol 14, 379-385.

Spring, S., Jäckel, U., Wagner, M. \& Kämpfer, P. (2004). Ottowia thiooxydans gen. nov., sp. nov., a novel facultatively anaerobic, $\mathrm{N}_{2} \mathrm{O}$ producing bacterium isolated from activated sludge, and transfer of Aquaspirillum gracile to Hylemonella gracilis gen. nov., comb. nov. Int J Syst Evol Microbiol 54, 99-106.

Strength, W. J., Isani, B., Linn, D. M., Williams, F. D., Vandermolen, G. E., Laughon, B. E. \& Krieg, N. R. (1976). Isolation and characterization of Aquaspirillum fasciculus sp. nov., a rod-shaped, nitrogen-fixing bacterium having unusual flagella. Int $J$ Syst Bacteriol 26, 253-268.

Tamaoka, J. \& Komagata, K. (1984). Determination of DNA base composition by reversed-phase high-performance liquid chromatography. FEMS Microbiol Lett 25, 125-128.

Terasaki, Y. (1973). Studies on the genus Spirillum Ehrenberg. II. Comments on type and reference strains of Spirillum and description of new species and subspecies. Bull Suzugamine Women's Coll Nat Sci 17, 1-71.

Terasaki, Y. (1979). Transfer of five species and two subspecies of Spirillum to other genera (Aquaspirillum and Oceanospirillum), with emended descriptions of the species and subspecies. Int J Syst Bacteriol 29, 130-144.

Wauters, G., De Baere, T., Willems, A., Falsen, E. \& Vaneechoutte, M. (2003). Description of Comamonas aquatica comb. nov. and Comamonas kerstersii sp. nov. for two subgroups of Comamonas terrigena and emended description of Comamonas terrigena. Int J Syst Evol Microbiol 53, 859-862.

Yoon, J.-H., Kim, H., Kim, S.-B., Kim, H.-J., Kim, W. Y., Lee, S. T., Goodfellow, M. \& Park, Y.-H. (1996). Identification of Saccharomonospora strains by the use of genomic DNA fragments and rRNA gene probes. Int J Syst Bacteriol 46, 502-505.

Yoon, J.-H., Lee, S. T. \& Park, Y.-H. (1998). Inter- and intraspecific phylogenetic analysis of the genus Nocardioides and related taxa based on 16S rRNA gene sequences. Int J Syst Bacteriol 48, 187-194.

Yoon, J.-H., Kang, K. H. \& Park, Y.-H. (2003). Psychrobacter jeotgali sp. nov., isolated from jeotgal, a traditional Korean fermented seafood. Int J Syst Evol Microbiol 53, 449-454. 